\title{
Internationalisation and migrant academics: the hidden narratives of mobility
}

\author{
Louise Morley ${ }^{1} \cdot$ Nafsika Alexiadou $^{2} \cdot$ Stela Garaz $^{3}$. \\ José González-Monteagudo ${ }^{4} \cdot$ Marius Taba $^{5}$
}

Published online: 25 January 2018

C The Author(s) 2018. This article is an open access publication

\begin{abstract}
Internationalisation is a dominant policy discourse in the field of higher education today, driven by an assemblage of economic, social and educational concerns. It is often presented as an ideologically neutral, coherent, disembodied, knowledge-driven policy intervention - an unconditional good. Mobility is one of the key mechanisms through which internationalisation occurs, and is perceived as a major form of professional and identity capital in the academic labour market. Yet, questions remain about whether opportunity structures for mobility are unevenly distributed among different social groups and geopolitical spaces. While research studies and statistical data are freely available about the flows of international students, there is far less critical attention paid to the
\end{abstract}

Louise Morley

L.morley@sussex.ac.uk

Nafsika Alexiadou

nafsika.alexiadou@umu.se

Stela Garaz

stela.garaz@gmail.com

José González-Monteagudo

monteagu@us.es

Marius Taba

tabamarius@yahoo.com

1 Centre for Higher Education and Equity Research (CHEER), Department of Education, University of Sussex, Essex House, Falmer, Brighton, East Sussex BN1 9QQ, UK

2 Department of Applied Educational Science, Umeå University, Umeå 901 87, Sweden

3 Independent Researcher (former Program and Studies Officer, Roma Education Fund, Budapest), Vienna, Austria

4 Department of Theory \& History of Education, and Social Pedagogy, University of Seville, Pirotecnia street, s/n., Seville 41013, Spain

5 Institute of Sociology and Social Policy, Corvinus University of Budapest, Room 424 (Floor IV) Kozraktar utca 4-6, Budapest H-1093, Hungary 
mobility of academics. Drawing on semi-structured interviews with 14 migrant academics from diverse ethnic backgrounds, including Roma and Latin American communities, and the theoretical framings of the new mobility paradigm and cognitive and epistemic justice, this article explores some of the hidden narratives of migrant academics' engagements with mobility in the global knowledge economy. It concludes that there is a complex coagulation of opportunities and constraints. While there are many gains including transcultural learning, enhanced employability and inter-cultural competencies, there are also less romantic aspects to mobility including 'otherness', affective considerations such as isolation, and epistemic exclusions, raising questions about whose knowledge is circulating in the global academy.

Keywords Internationalisation $\cdot$ Migrant academics $\cdot$ Mobility $\cdot$ Identity $\cdot$ Roma $\cdot$ Epistemic justice

\section{Introduction: mobility as the new capital in the global knowledge economy}

Internationalisation is a dominant policy discourse in higher education today. It is invariably presented as an ideologically neutral, coherent, disembodied, knowledge-driven policy intervention - an unconditional good. Yet, it is a complex assemblage of values linked not only to economic growth and prosperity, but also to global citizenship, transnational identity capital, social cohesion, intercultural competencies and soft power (British Council 2012; Clifford and Montgomery 2014; De Wit et al. 2015; Kim 2017; Lomer 2016; OECD 2012; Stier 2004). Mobility is the sine qua non of the global academy (Sheller 2014). International movements, flows and networks are perceived as valuable transnational and transferable identity capital and as counterpoints to intellectual parochialism. Fluidity metaphors abound as an antidote to stasis e.g. flows, flux and circulations (Urry 2007). For some, internationalisation is conceptually linked to the political economy of neoliberalism and the spatial extension of the market, risking commodification and commercialisation (Matus and Talburt 2009). Others raise questions about what/whose knowledge is circulating and whether internationalisation is a form of re-colonisation and convergence that seeks to homogenise higher education systems (Stromquist 2007). Internationalisation policies and practices, it seems, are complex entanglements of economic, political, social and affective domains. They are mechanisms for driving the global knowledge economy and the fulfilment of personal aspirations (Hoffman 2009). Academic geographical mobility is often conflated with social mobility and career advancement (Leung 2017). However, Robertson (2010: 646) suggested that 'the romance of movement and mobility ought to be the first clue that this is something we ought to be particularly curious about'.

As five academics working in Austria, Hungary, Spain, Sweden and the UK, whose countries of origin include Greece, Moldova, Romania, Spain and the UK, we are curious about the hidden narratives of mobility. We have diverse socio-economic, linguistic, disciplinary and ethnic backgrounds including one Roma colleague. We are aged between $30 \mathrm{~s}$ and $60 \mathrm{~s}$, with considerable individual and collective experience of working internationally. We are mindful that while internationalisation is conceptualised as a form of desirable capital for institutions and individuals, traditional notions of space and place are disrupted. New openings can be accompanied by risks of the reproduction of social and national hierarchies and closures, and an unequal distribution of benefits across different social groups and geopolitical regions. The international marketisation of higher education, new geographies of knowledge, spatial politics and changing mobility flows have social implications (Equality Challenge Unit 2009, 2010, 2011, 2013). For example, who is perceived as the ideal mobile subject? Is mobility always strategic, and voluntary, or coercive, 
structural and contingent, as in the case with the current refugee crisis, conflict and political upheaval? (Bauder 2015; Morrice 2017). Whose knowledge is circulating? Sheller (2014:3) suggests that 'space is treated as an empty container for social processes'. People are conceptualised as chess pieces or resources to be dislocated and relocated around the globe, with limited consideration of identity, community, epistemic inclusion, care or the affective domain.

Theorising mobilities, Urry (2007) argued that there is a minimisation of the significance and consequences of embodied experiences of movement. In the field of higher education studies, extensive literature exists on student mobility in the global academy (e.g. Bhandari and Blumenthal 2011; Brooks 2017; Guruz 2011; Krzaklewska 2008). Fewer studies explore mobility and opportunity structures in relation to academics (Ackers 2008; Bedenlier and Zawacki-Richter 2015; Bönisch-Brednich 2016; Cai and Hall 2015; Fahey and Kenway 2010; Hoffman 2009; Kim 2008, 2009a, 2009b, 2010, 2017; Kim and Locke 2010; Musselin 2004; Pherali 2012). Kim and Locke (2010) and ECU (2014) call for qualitative studies to uncover the stories behind the sparse statistics. Our small-scale qualitative inquiry aims to engage with the social, affective and epistemic consequences of academic migration, especially in relation to equity and inclusion. Using the theoretical approaches of the new mobility paradigm (Sheller and Urry 2006), and epistemic justice (Fricker 2007) to analyse the personal accounts of migrant academics collected through 14 semi-structured interviews with academics in social science and humanities disciplinary locations, our article aims to highlight some of the hidden narratives of internationalisation for migrant academics.

\section{Mapping multiple mobilities}

Statistical data on academic mobility are limited. There is research on the dynamics of mobility and its relationship to particular geographical regions and higher education systems (Bedenlier and Zawacki-Richter 2015; Teichler et al. 2013), but little data about career-related mobility. While several European Higher Education (EHEA) countries have national policy goals explicitly aimed at promoting academic staff mobility (EHEA 2015), less than half of the member countries collect information on participation rates in international mobility among researchers, teachers or doctoral candidates. One study of academics' internationalisation reports large variations in the share of University employees with international backgrounds, ranging from 18 to $23 \%$ in Finland, Norway, the UK and USA, and 3-9\% in France, Japan and Spain (De Wit et al. 2015). In another study based on data collected from 1336 higher education institutions, significant numbers of institutions report up to $10 \%$ of their faculty members with at least 1 year's experience working abroad, and more widespread practices of faculty members engaging in short-term international research stays (EgronPolak and Hudson 2014:15). Drawing on data from HESA (2009), Kim and Locke (2010) address academic mobility in their chapter in the research report on the quantitative Changing Academic Profession project, highlighting how 27\% of full-time academic staff appointed in 2007/2008 came from outside the UK. Lack of accurate and systematic information on academic mobility has been highlighted as problematic, especially for monitoring the equality dimensions of mobility. The UK's Equality Challenge Unit (ECU 2014) wants more extensive surveys to map processes and practices, but also argues for supplementary in-depth and qualitative understanding of the mobility experience, as 'telling stories is much more compelling than the data' (ECU 2014: 13).

Existing studies on transnational academic mobility suggest that there is no universal model characterising how academic mobility is experienced or performed. Mobility drivers are contextual and contingent in sending and hosting countries. The nature and duration of mobility, opportunities and constraints for being mobile differ significantly, and are often bound to academics' gender, 
ethnicity, age, socio-economic status and indeed disciplinary location. There are differences within differences including chosen or forced mobility, the kinetic elite and the reserve and sometimes disposable labour force, nomadic and channelled mobilities as well as different velocities and temporalities. Professional stays abroad are often perceived as essential for academic identity formation, recognition and credibility and capacity building (Leemann 2010; Morano-Foadi 2005; Kyvik et al. 1999). Particular research projects, reputation of host institutions, access to better research infrastructures and cultural and historical interests for a specific location have also been identified as drivers (Jöns 2007). Limited academic employment opportunities and financial and resource constraints in the country of origin can also drive international mobility, especially for early career academics (Guth and Gill 2008; Jöns 2007).

Women in academia are generally less mobile than their male counterparts, especially at later career stages, which can be attributed to traditional gender roles and the intersection of sexism and ageism in recruitment practices (Giorgi and Raffini 2015; Leemann 2010). They are also less likely to participate in international mobility as academic hosts (Jöns 2011). Younger academics, building their careers, tend to be more internationally mobile than senior colleagues (Auriol 2010). Regarding the nature of mobility, academic staff fulfil diverse functions in their host countries, including teaching, research, management duties or a combination of those (Kim 2009a, b, 2010). Kim (2008: 579) posited a typology of migrant academics that included three broad categories:

Academic intellectuals, whose creative role is to engage as 'legislator' and 'interpreter' contributing to a 'creative destruction' and reconstruction of the paradigms of academic work; Academic experts, many of whom increasingly define their roles as 'researchers' with transferable methodological research skills; and Manager-academics, many of whom have assumed their role as general managers with transferable management skills rather than traditional academic leadership.

Patterns and purposes of transnational mobility vary, in terms of duration, from short-term stays to permanent settlement, as our data reflect (Bauder 2015). For example, some academics move once and re-moor in one new country, while others move every few years, with no fixity. Another variation is circular mobility from the home institution to one or several host institutions, often involving multiple calculations and cycles of accumulation of diverse capital. Whatever the configuration, the simplistic binary of mobility versus fixity is itself in flux.

\section{Policy agenda for international academic mobility}

Lack of data is surprising as the last 30 years have seen a rise in policy discourses that place higher education and internationalisation at the heart of economic and social development. Internationalisation is integral to the global knowledge economy (Jessop 2016; OECD 2004; Verger 2010). The Organisation for Economic Co-operation and Development (OECD) endorsed 'cross-border higher education' that can meet 'human, social, economic and cultural needs' (Vincent-Lancrin and Pfotenhauer 2012:5). There is a regional dimension to these agendas, with distinct manifestations in the developments of higher education in East Asia, Latin and North America, Africa and the Middle East (Kim 2016; Streitwieser 2014; Verger and Hermo 2010), with some regions characterised as exporters while others as importers of models of research knowledge, and academic staff (Kim 2009a, b). Across Europe, the evolution of the Higher Education Research Area, and a more intensified education and lifelong learning policy since 2000, led to the adoption of 'knowledge mobility' as the 'fifth freedom' - a core discourse in the Bologna Strategy but also the 
European Union policy developments (Chou and Gornitzka 2014; Council of the European Union 2009; European Commission 2013; EHEA 2012). These issues raise normative questions about the power differentials between institutions and countries in the new global economy of knowledge (Fahey and Kenway 2010; Jessop 2016; Pavlin et al. 2013).

\section{Methodology for mobility}

We sought some of the narratives behind the (sparse) statistics and enthusiastic policy directions. Our article is based on 14 semi-structured interviews with migrant academics, working currently or recently in universities in Hong Kong, Hungary, Kazakhstan, Japan, Poland, Qatar, Spain, Turkey, UK and the USA. Their countries of origin were Austria, Colombia, Ghana, Guatemala, Mexico, Poland, Romania, Serbia, Portugal, UK and the USA. The sample was selected through personal and professional networking paying attention to gender, ethnicity, age and countries of origin and employment. They represented different career stages of mobility including $\mathrm{PhD}$ researchers, lecturers and assistant, associate and full professors. Nine of our participants were women and five were men. They were aged between late 20s to mid 60s. Four participants were of Roma ethnic origin, four were Latin American, one was from Sub-Saharan Africa and one was mixed race African American and European. Most of the participants were fluent in two or more languages. Regarding disciplines, the participants were in the fields of social sciences and humanities. We acknowledge that the findings are not necessarily generalisable to the STEM disciplines as these are already highly internationalised. van der Wende (2015) suggests that it has long been accepted that mobility enhances scientific innovation as it allows migrant scientists to match their particular knowledge with those of others and to work in places where their specialisation is well-resourced.

Our participants also represented multiple mobilities. The United Nations defines migrants as persons who have lived outside their country of birth for 12 months or more (Castles and Miller 2009:5), but beyond this formal definition we recognise that there are many diverse ways of conceiving and portraying mobilities. In some cases, academic mobility for our participants was driven by a quest for new, but often short-term professional or economic opportunities. Migration often followed historical colonial connections e.g. from the UK to Hong Kong. It could also be constructed as a form of neo-colonialism, with the leaders in the global knowledge economy experiencing more opportunities for mobility, and offering scholarships and bursaries to academics from lower-income countries. Migration was frequently within the Global North including from Northern Europe or the USA to countries where migrant academics were actively recruited to increase internationalisation and build capacity of universities in a competitive academic and research landscape, for example, in East Asia or the Middle East. Some were part of the Transnational Education industry, employed by a university in the Global North, but posted to its overseas branch campuses. Another type of mobility involved moving from the Global South to the Global North for economic, political and human rights motivations. This was the case with our four Latin American academics living and working in the USA. For them, migration was perceived as a long-term commitment. For some, mobility was temporary including visiting fellowships or doctoral scholarships. Among our Roma participants, mobility was often from lower-income to higher-income European countries. Some participants were migrant teachers, while others moved across borders for their international research. Our research posed some ethical challenges about how to protect participants' anonymity when fields and representation were limited and individuals easily identifiable e.g. Roma academics. Hence, we sometimes present participants without specifying identifiable socio-demographic characteristics. 
All interviews were conducted in English and transcribed and coded, drawing on thematic and dialogic analysis. We were interested in not only the 'what' (themes and contents), but also the 'who', 'when' and 'why' (Riessman 2008, 53-76; Wengraf 2001), opening the research and analytical process to questions of relationships, context, complexity, power and the diversity of knowledges and knowers (Merrill and West 2009). Our methodology was informed by a combination of inductive, emerging coding and deductive coding from the literature review, and the objectives of the European project from which this article emerged. We paid attention to causal conditions, events and incidents, strategies, context and intervening conditions, action/interaction and consequences (Gibbs 2007: 86-88). We identified key debatable issues that show opportunities, constraints and the politics of knowledge regarding mobilities and internationalisation of under-represented and disadvantaged groups.

We recognise that we are currently in a highly pluralistic moment of social research. Thus, postmodern, post-foundationalist, post-structuralist and indeed post-qualitative perspectives inform our research, influenced by life history, feminist studies and biographical approaches (Bruner 1991; Roberts 2002; Maclure 2013; Merrill and West 2009). The interviews focused on narrating and exploring life itineraries, personal and professional experiences of mobility and internationalisation (Atkinson 1998; Clandinin and Connelly 2000; Miller 2000; Wengraf 2001). Interviews initially encouraged narratives and personal accounts, aimed at exploring and identifying meaning-making and individual engagements, and progressed to discussing cultural and professional contexts; mobility drivers or motivations; personal and professional benefits and disadvantages; factors that contributed to positive or negative experiences; and how internationalisation interacted with their social identities. Participants were also asked about support needs, and what training and formal and informal interventions would be helpful to support mobility? Their responses have been incorporated in a Training Module Internationalisation in Higher Education: Practical Guidance [1]. This intervention reflects our commitment to promoting a research process that effects multilevel, long-term changes to enhance international mobility of disadvantaged, marginalised groups.

\section{Theorising academic mobility}

Theoretically, we drew upon two central approaches: the new mobility paradigm in the social sciences which studies the interdependent movements of people, information, images and objects (Sheller and Urry 2006; Sheller 2014; Urry 2007), and epistemic justice (Fricker 2007). New mobility research interrogates who and what is de-mobilised and re-mobilised. It interrogates what is at stake in debates over differentiated mobility, and recognises that movement and spatial fixity are always co-constituted. Mobility is embodied, but is also discursive and material involving the production, distribution and relay of power and power relations. Cresswell (2010: 18) suggests that 'mobility involves a fragile entanglement of physical movement, representations, and practices', and is 'a resource that is differentially accessed' (p. 21).

Academic mobility can mean that new knowledge is produced, emergent knowledge is exchanged, disseminated and validated, and knowledge networks and collaborations are formed (Jöns 2011). Epistemic justice explores the right of multiple forms of knowledge to co-exist and the plurality that recognises the diversity of knowledges and the equality of knowers. Fricker (2007) identifies two types of epistemic injustice: testimonial and hermeneutical. Testimonial injustice involves a deflated level of credibility to a speaker's world. Hermeneutical injustice is a gap in collective interpretative resources. Some social groups are wronged in their capacity as knowers, suffer a credibility deficit and lack rational authority. The ultimate cause of both injustices is 
prejudice against certain speakers (Anderson 2012). Fricker (2007:71) suggests that we rely on various markers of credibility, and that these are often based on stereotypes. These markers are frequently attached to particular social identities, and authority does not 'stick' to certain bodies (Ahmed 2000). For migrant academics, this can mean that those coming from the Global South often have to navigate credibility assessments in relation to norms from the Global North.

\section{Migrant academics as 'other': a complex coagulation of opportunities and constraints}

Migrant academics, as strangers, can occupy liminal spaces in the global academy (Ahmed 2000; Bönisch-Brednich 2016; Kim 2017). This positioning has the potential to provide externality and new insights into how the knowledge economy is experienced materially, intellectually, socially and affectively. The narratives of our 14 migrant academics, as knowledge workers, suggested that experiences of mobility were contextual, contingent and contradictory. It was rare to find that mobility was totally positive or negative. Rather, it offered a complex coagulation of opportunities and constraints. Participants narrated the positive influence of international mobility on professional development including the expansion and diversification of professional networks and soft power. In this regard, a Roma academic explained how her mobility provided opportunities for the accumulation of academic and social capital.

... in [my host city], you know, they are from across Europe, and sometimes even from different continents. And this is something that stays with you for a long time... And eventually at some point, some of these friendships or networks might actually help you with your academic career as well.

Expanding one's global reach, as the above academic identifies, enhances credibility markers, visibility and validation. This is particularly important for marginalised communities such as the Roma. While the policyscape is changing including a new phase in European Union policy, accompanied by the extension of freedom of movement to new accession countries in 2004, and especially in 2007 (van Baar 2012), Roma academics are still few in number. To counter this underrepresentation, Roma participation in higher education and student and faculty mobility have been promoted by organisations including the Central European University and the Roma Education Fund. Mobility across sectors has also been enabled by the requirement for some European Union funded research programmes for universities to form wider partnerships, involving civil society in the spirit of what Gramsci (1995) described as organic intellectuals. The HEIM Project's partnership $^{1}$ between universities and the Roma Education Fund is an example, of how knowledge can be created and exchanged for Roma participation in internationalisation.

However, internationalisation for marginalised groups can sometimes exacerbate exclusion. Fahey and Kenway (2010: 630) noted: The exilic intellectual has little sense of belonging. Loss of citizenship and associated identifications were reported in our study as mobility left some people feeling that they could not invoke a fixed national identification. A Roma academic discussed the detachment or de-territorialisation of global citizenship and multiple identities:

\footnotetext{
${ }^{1}$ The HEIM project focuses on how principles of equity and inclusion can be applied to internationalisation strategies and programmes in higher education, as well as on developing research and innovation capacity in this field. Research focuses on the Roma community in Europe as a critical example of a marginalised group, at both staff and student levels.

http://www.sussex.ac.uk/education/cheer/researchprojects/rise
} 
Sometimes you might feel split... my house, my home, is Budapest yes. Here is my [spouse], my child, family... And that's our home in a way... I do not identify myself as a Hungarian at all. On the other hand, I have my daughter who was born here, went to kindergarten... she identifies herself both as a Hungarian, as a [national of my home country], as a Roma and sometimes even as an American because she speaks English.

These observations suggest a 'queering' of identity, and that the very notion of nationality for migrant academics in a global knowledge economy could be an archaic, modernist construction. Roma participants often identified more with their transnational ethnic group than with their countries of origin. For one Roma academic, border-crossing was her intellectual project:

I've always been interested in transnational research projects ... I was trained to be a multisited researcher ...The research work itself has always been on things that cross borders.

This Roma academic's research interests contribute to establishing hermeneutical justice as actual and perceived nomadism and de-territorialisation have historically excluded Roma communities from opportunities for education and knowledge production (Maestri 2017). For Roma academics in our study, international mobility was seen as an epistemic as well as a social opportunity. It enabled them to create and advance knowledge of Roma issues and counter negative labelling and categorisation processes. It marked them as knowledge producers, or subjects, rather than objects of inquiry. In the 1970s, there were around 30 researchers in the field of Romani Studies, but the European Academic Network on Romani Studies when established in 2011 achieved a membership in excess of 350 academics (mainly non-Roma) from 70 different universities and research institutions in more than 20 different countries.

Our four Roma participants offered insights into how their identities as members of a socially marginalised ethnic group interacted with internationalisation. One advantage of mobility was that this connected them with an international Roma community. One Roma participant explained how she had consolidated her community or critical mass of Roma intellectuals beyond the borders of individual countries:

... the possibility of being mobile in terms of my work, in terms of my networks, connections, communities, really opens up... I mean that's amazing and I do feel like I am accountable to Romani community and Romani academics all over the world literally... It influences the possibilities for mobility because there is a way in which you're in contact with people everywhere.

The issue of accountability also suggests that some migrant academics - especially those from socially excluded groups - are not self-contained, free-floating, capital accumulating agents and entities, but are in circular relation to their wider communities. This multiplier effect i.e. getting in a better position for developing or influencing one's own community, or challenging stereotypes, was also discussed by a Roma academic working internationally:

I've leaned much more heavily ... on trying to find ways to actually bring support from say the US and the UK, like financial support to my colleagues ... in Romania, in Bulgaria, in Serbia, like in sort of ex-Yugoslavia, in Hungary to some extent.

In this analysis, mobility is perceived as re-distribution of capital from the Global North to the actual or symbolic Global South. Mobility also enabled Roma academics to recast negative and stigmatised identities in their countries of origin to that of global citizenship. In this case, spatial mobility could mean social mobility. However, social mobility 
is a problematic concept implying that it is desirable to leave one's community of origin behind (Walkerdine 2003). Roma academics described prejudice in their home and international academic communities. One felt that her international orientation interacted with stereotypes about Roma nomadism, rootlessness and marginality: I've had a [manager] who said something like, oh; you're still doing the gypsy thing? Her internationalism, intersecting with Roma identity, was recast as feckless, unstable and undesirable. For some Roma participants, negative social identities pursued them internationally. An Eastern European Roma academic related how, when she was studying in the UK, another student from her country of origin remarked: Oh but you don't look like Roma. She felt like she's supposed to make me feel better with this. This celebration of ethnic mimicry, or successful/ privileged passing, was an example of another type of mobility — one that was experienced as highly offensive.

\section{Hidden injuries: the materialities of mobility}

Migrant academics' de-territorialised and re-territorialised positions were characterised by precariousness, involving a range of affective considerations and hidden injuries including the insecurity of short-term contracts and visa arrangements, second-class citizenship and transient relationships (Giorgi and Raffini 2015; Hoffman 2009; Richardson and Zikic 2007). The social impact of re-location can be a form of dislocation and displacement, requiring active engagement with 'otherness' (Kim 2010). Difference and being 'other' were dominant themes - sometimes posed in terms of the experiences of racism and sexism, or social privilege, as a UK academic in Hong Kong observed:

There were many people in Hong Kong from England or the US, and they might have been working there 20 years, 30 years... living in a ... bubble wrap culture where they had a nice flat and they would go to an expat bar or something. And, in fact, you never really need to bump into any locals in that process. Or at least you're not meeting them in a sort of authentic way.

The power relations explicated in the above observation suggest that for some, isolation is a choice, whereas for others it is an imposed mobility tariff. The affective implications of being an outsider in their host countries were a cost of expatriation. 'Otherness' was often abstract, even when there was a shared language and Global North location, as a US academic working in the UK explained:

Being an outsider to the UK means that there is always sort of a layer of difference in interests between myself and a person that I speak to.

'Layers of difference' had diverse material consequences, with some forms of difference experienced as negative professional equity. 'Otherness' and power differentials of racism, discrimination and prejudice were highlighted by participants moving from the Global South to the Global North, or from marginalised Roma communities to the 'mainstream'. This was experienced in tangible ways such as failure to gain tenure or promotion as a Mexican academic in the USA noted: I've gone up for promotion to full professor twice, and I've been declined twice. It was often felt in more abstract affective micropolitical daily relays of power (Morley 1999), as described by a Guatemalan academic working in the USA: 
You're constantly being positioned, right, so I have to be ultra-careful in terms of what I say in faculty meetings, being the only one of 20 white other faculty members because everything I say is raced and gendered.

Precarity related to everyday practices, as well as to professional contracts, with the above academic highlighting how her difference imposed a fragility in social relations, as her every utterance could either prove or counter stereotype credibility assessments. Racialised and gendered power were believed to operate in divisions of labour and some participants felt that migrant academics from the Global South were overloaded with teaching responsibilities, or tokenised by being the one 'person of colour' on committees.

Corporeal travel can be read as an indicator of intellectual and social flexibility and openness in the global academy. Internationalisation is perceived as desirable capital as it indicates transcultural learning, language acquisition and theoretical cosmopolitanism, but it is accompanied by the risk of loss of stability, as an American/European academic suggested:

The more willing you are to be mobile, the more likely you're going to be able to get posts that are interesting... To the point that a lot of the job descriptions say experience working internationally, experience outside of your home country, so the more you have the better but it also means the less likely you are to settle down.

'Settling down' or fixity seems to be in marked contrast to the opportunities that mobility can offer. As the above academic observed, the willingness to dislocate from national identities and opt for a more fluid and responsive mode of existence can carry an important premium in the global knowledge economy.

Structures of inequality frequently intersected in the narratives of marginalisation, and power relations informed mobility processes and practices. The ideal mobile subject was perceived to be young, male, able-bodied and white. A female Austrian academic highlighted the embodied nature of migration and believed that mobility favours

Persons without care responsibilities...you need a wealthy background. I think, a healthy physical constitution is also an important factor.

Gender interacts significantly with opportunity structures for mobility (Jöns 2011; Lynch 2009). It is also a marker in epistemic hierarchies, with women traditionally excluded, misrecognised and marginalised from knowledge production. Mobility as a valuable resource is not open to everyone and often overlooks the gendered, sexualised and racialised constraints on freedom of movement. Skeggs (2004: 48) argued that the (old) mobility paradigm could be linked to a 'bourgeois masculine subjectivity' that describes itself as 'cosmopolitan'.

Traditional gender regimes can also be a push factor. A Colombian academic in our study migrated to the USA, believing that her recent divorce would be a form of negative equity in Colombia. Gender was both a noun and a verb e.g. it related to social identity and to how academic processes and practices are gendered. A UK academic reported his responses to different gender regimes:

I found some of the attitudes of some of the male professors ... prehistoric maybe...In Hong Kong, it's quite common that everyone on the (conference) panel is a man, and nobody's going to question it.

The norm of privileged men as the only legitimate knowledge producers could be disrupted by the externality of the migrant's critical gaze, as the above academic suggested. However, 
elitism was cited as an example of how internationalisation intersected with social and cultural capital, as an Eastern European academic in the UK observed

I think the racism is so vicious that you must be a very special elite Roma to be able to access all these opportunities... if you are a Roma and working class, everything is closed to you.

As the above quotation suggests, mobility is not always a democratic process. There are uneven immigration and visa regulations, involving increasing amounts of surveillance and regulation. As a result of conflict, terrorism and global insecurity, border-crossing is becoming a risky business. This results in more inequalities for academics from countries experiencing war, poverty or global risks. For example, citizens from some Islamic countries including Libya, Syria and Iraq can travel with their passports to between 30 and 36 countries. However, citizens from Germany, Sweden, Spain, Finland, France, Italy and the UK are permitted to travel to between 175 and 177 countries. We have yet to see the impact of Brexit on mobility between the UK and the European Union, and the Trump Administration's travel ban on citizens from six Islamic countries. As Arnot et al. (2013: 68) observed: The politics of immigration reveals a good deal about the cultural ethos of countries. One of our Latinix participants described how borders were often liminal places at which movement is paused, slowed or stopped (Mountz 2010):

It was a traumatic experience also because at the airport, they asked me ... Where are you originally from? And that's the question that I always fear... I knew that the minute I said Colombia, they were going to stop me and interrogate me ... So they held me there for two hours and they were threatening to deport me.

While some borders, or borders for some, are becoming porous or virtual spaces, others are material sites of control and surveillance, as the above academic describes. The ideal migrant academic needs to be flexible and rapidly transportable, as risk is often endemic, but these flows can be impeded by geopolitical power relations.

The materiality of mobility was a recurring theme in our research. Mobility can both develop and challenge cultural competences. The cliché of culture shock was discussed e.g. lacking the capital to interpret and understand situational etiquette, or spatially fixed geographical containers for social processes (Sheller and Urry 2006). A UK academic in Japan described how he had learned new protocols in institutional cultures of presenteeism in which academics were expected to work business hours, without the UK's flexible working patterns:

I was asked to go to a conference in Tokyo ... I would have to formally ask the permission of the professor or the head of department. Even though he was always going to say yes, if I hadn't asked permission it would have been considered rude.

Internationalisation in Japan, as Poole (2016) argues, is often impeded by the rigidities of a bureaucracy which does not allow for difference or deviation.

A US/European academic observed that failure to acquire cultural competences could have material repercussions, resulting in disrupted mobility:

You learn on the job... when to speak, when not to speak, what the definition of saving face means because saving face in certain cultures is a huge deal. I've seen people not get their visas renewed because they haven't learnt to negotiate the system. 
She also uncovered the underbelly of romantic mobility discourses:

There's this expression called the 'midnight run' which is basically people who are uncomfortable in the setting, ... who are just so unhappy in the situation that they literally, quietly pack up their stuff, catch a late night flight ... the turnover rates and the amount of people who don't go past one year, who manage to stick out the year but then say no. I mean, it's a real issue in this sort of field.

Mobility, as the above academic reports, can be associated with friction, turbulence and an unbearable affective load. Velocity can be applied to the speed and rapid transitions of exit as well as entry (Cresswell 2014). This is the narrative that is frequently hidden from popular policy discourses. While offering a range of professional and intellectual opportunities, mobility involves diverse disjunctures and disconnections that are not always perceived as a happiness formula (Ahmed 2010).

\section{Internationalising knowledge}

Knowledge, mobile or otherwise, is never neutral. Participants migrating from the Global South to the Global North discussed epistemic injustice. They felt that while they had gained materially as knowledge workers, they had often been misrecognised or disqualified as knowledge producers. The signifiers of their lost credentials often related to language and accent, or skin colour and negative framings of their country of origin. A Ghanaian academic in the UK observed:

So people, not just in the university, but outside the university... have no idea of what you bring and who you are and what you can contribute.

As the above academic describes, one needs international capital in order to be able to read international capital. In many universities, the international was associated with the market, rather than with epistemic expansion. The Equality Challenge Unit's (2013) UK research found that many universities have dedicated staff to support international students, but not international staff. While talent was being sought (UUK 2007), it was often under-utilised in practice, and universities might be under-appreciating the knowledge and experience that international staff bring. Some participants reported that they had developed intellectual capital, professional networks and reach, but others felt that that they had lost research and publication opportunities as they had been positioned as domestic labourers in the knowledge economy focussing on student support, teaching and administration, rather than on more outward-facing activities. Others described loss of academic freedom e.g. a US/European lecturer was told by her Gulf region university to stop teaching about Jewish or gay sociologists i.e. Zygmunt Bauman and Michel Foucault!

Epistemic justice (Fricker 2007) raises questions about who has the right to create knowledge and the lack of knowledge that exists about marginalised communities. A Roma academic believed that Roma were not perceived as authentic scholars: Your knowledge that what you produce is questioned because it's for some reason perceived as not being objective. Her observation relates to Fricker's (2007) concept of testimonial injustice i.e. the deflated level of credibility to a speaker's world. A female Guatemalan academic in the USA touched con Southern Theory (Connell 2007) and de Sousa Santos's (2014) 'epistemologies of the south' and explained how people in the Global South are expected to be the objects of knowledge constructed in the Global North, rather than knowledge agents: 
It's just so hard to be a faculty member of colour and an immigrant at the same time because the culture of academia is not made for us... our experiences tend to be not valued or they feel threatening, you know, because when you have a bunch of white professors that are experts in race and ethnicity, and then a person of colour comes in that's the expert, that's a...tension.

Claiming epistemic authority as a member of a marginalised group, and indigenising humanities and the social sciences, as the above academic explained, disrupts knowledge hierarchies and hegemonies (Omobowale and Akanle 2017). One of our Roma participants discussed the absence of scholarship on Roma by Roma, and how she felt disqualified, even in the field Romani Studies.

I think many times we as Roma we feel kind of, marginalised, you know? In the Romani Studies as a discipline... The Gypsy Lore Society Conferences which are the biggest events of Romani Studies every year...there's hardly any Roma, really, hardly any Roma there.

Who has the right to think, to know, as this academic questions, and is international knowledge invariably linked to re-colonisation? Questions were raised by a Mexican male academic in the USA about the geopolitics of knowledge and hermeneutical injustice i.e. the gap in collective interpretative resources that means that some forms of knowledge and knowing are misrecognised, unintelligible or absent (Fricker 2007).

When we come into this country, we learn about everything and everybody, except ourselves. And so what we began to do was, how do we use learning and the learning process as a tool for identity formation?

His views evoke Mignolo's (2009) observations about ontology and epistemology:

rather than assuming that thinking comes before being, one assumes instead that it is a racially marked body in a geo-historical marked space that feels the urge or gets the call to speak.... (Mignolo 2009: 2).

Our Mexican participant believed that negative experiences of academia fuelled creation of alternatives and that universities needed to consider how the future would be different from the present in relation to the inclusion of excluded groups. Said's (1994) concept of 'exilic thinking', according to Fahey and Kenway (2010), is representative of criticality itself, as it means positioning oneself as an outsider in opposition to orthodoxies. Internationalisation and experiences of 'otherness' can transform knowledge: 'Exile for the intellectual in this sense is restlessness, movement, constantly being unsettled, and unsettling others' (Said 1994: 39). While there was considerable diversity of experience in our sample, their sensibilities to power, difference and diversity had often been heightened by their dislocation suggesting that mobility is about more than globalised academic capitalism and the export and commodification and mercentilisation of knowledge workers in the global academy, but is also central to knowledge production itself (Cantwell and Kauppinen 2014).

\section{Concluding comments}

Higher education internationalisation is often seen as an unconditional good, which is one of the reasons why it is promoted through institutional, regional and global policy discourse. This could be post hoc rationalisation for the marketisation and commodification of higher 
education. Internationalisation could also be a site of enhanced opportunity structures and the deparochialisation of knowledge. With a focus on 14 migrant academics' narratives, our article explores how academic mobility is experienced intellectually, socially and affectively. In line with the findings of other scholars (Bauder 2015; Jöns 2007), the article highlights the lack of a universal model of academic mobility, arguing that it is characterised by a diversity of geographical patterns, motivations, constraints and outcomes. While there is no doubt that internationalisation in higher education brings many social, professional and material benefits including enhanced employability, inter-cultural competencies and global citizenship, there are encounters and engagements that are often disqualified from or silenced in official policy discourses and texts.

Academic mobility has identity implications that can be both positive and negative. Members of socially disadvantaged and marginalised groups can re-cast themselves as cosmopolitan global citizens, obtain transnational visibility and validation for themselves and their research interests, and at the same time become a valuable resource for their marginalised communities. However, negative identity positionings sometimes pursue them internationally-especially when they move from the Global South to the Global North, or from marginalised communities to mainstream academia. Gender discrimination can be a driver for academic mobility; at the same time, opportunities for being academically mobile still have a strong gender bias against women.

The less romantic side of academic mobility is mainly felt through the experience of 'otherness'. Migrant academics may be motivated by the identity capital and capacity building gained through mobility; at the same time, the feeling of de-territorialisation, loss of fixed national identification and loss of stability can be part of the experience. In some academic settings, migrant academics may feel more like knowledge workers than knowledge producers, constrained to absorb the local ways of (re)producing knowledge instead of actively contributing to creating it. This suggests that the circulation of knowledge in the global economy through internationalisation of higher education might be more limited than assumed.

The social and affective dimensions of international academic mobility need further research to determine the extent to which national socio-economic inequalities and constraints are transposed to international academic mobility. It would also be interesting to explore the hidden narratives of STEM migrant academics. The existence of good practices for assisting migrant academics to contribute as active knowledge producers and to cope with the feeling of 'otherness' and de-territorialisation should be mapped and analysed. Finally, the actual impact of international academic migration on global knowledge production requires exploration. The 'otherness' or externality of migrant academics offers new insights and challenges to some of the orthodoxies of academic life, and exemplifies some of the main arguments embedded in theories of epistemic justice, that is, that while physical bodies might be on the move, whose knowledge is included and circulated in the global knowledge economy.

Acknowledgements We wish to thank the European Union Horizon 2020 Framework Programme for Research and Innovation for funding the HEIM project (Grant number: H2020-RISE-2014-643739), the 14 interview participants, Emily Danvers for research assistance and the Centre for Higher Education and Equity Research (CHEER), University of Sussex, for their contribution to the data collection, and the anonymous reviewers for their constructive and supportive feedback.

Open Access This article is distributed under the terms of the Creative Commons Attribution 4.0 International License (http://creativecommons.org/licenses/by/4.0/), which permits unrestricted use, distribution, and reproduction in any medium, provided you give appropriate credit to the original author(s) and the source, provide a link to the Creative Commons license, and indicate if changes were made. 


\section{References}

Ackers, L. (2008). Internationalisation, mobility and metrics: a new form of indirect discrimination? Minerva, 46(4), 411-435.

Ahmed, S. (2000). Strange encounters: embodied others in post-coloniality. London: Routledge.

Ahmed, S. (2010). The promise of happiness. Durham: Duke University Press.

Anderson, E. (2012). Epistemic justice as a virtue of social institutions. Social Epistemology, 26(2), $163-173$.

Arnot, M., Schneider, C., \& Welply, O. (2013). Education, mobilities and migration: people, ideas and resources. Compare: A Journal of Comparative and International Education, 43(5), 567-579.

Atkinson, R. (1998). The life story interview. Thousand Oaks: Sage.

Auriol, L. (2010) Careers of doctorate holders: employment and mobility patterns. STI Working Paper, 2010/4. Paris, OECD. Available at: http://www.oecd.org/dataoecd/46/43/44893058.pdf. Accessed 14 July 2017.

van Baar, H. (2012). Socioeconomic mobility and neoliberal governmentality in post-socialist Europe. Journal of Ethnic and Migration Studies, 38, 1289-1304.

Bauder, H. (2015). The international mobility of academics: a labour market perspective. International Migration, 53(1), 83-96.

Bedenlier, S., \& Zawacki-Richter, O. (2015). Internationalization of higher education and the impacts on academic faculty members. Research in Comparative and International Education, 10(2), 185-201.

Bhandari, R., \& Blumenthal, P. (2011). International students and global mobility in higher education: national trends and new directions. London: Palgrave Macmillian.

Bönisch-Brednich, B. (2016). Rituals of encounter: campus life, liminality and being the familiar stranger. In A. Komisarof \& Z. Hua (Eds.), Crossing boundaries and weaving intercultural work, life, and scholarship in globalizing universities (pp. 118-130). London: Routledge.

British Council (2012). The shape of things to come: higher education global trends and emerging opportunities to 2020. British Council. https://www.britishcouncil.org/sites/default/files/the_shape_of_things_to_come_higher_education_global_trends_and_emerging_opportunities_to_2020.pdf. Accessed $\overline{14}$ Oct 2016.

Brooks, R. (2017). Understanding the higher education student in Europe: a comparative analysis. Compare: A Journal of Comparative and International Education. https://doi.org/10.1080/03057925.2017.1318047.

Bruner, J. (1991). The narrative construal of reality. In J. Bruner (Ed.), (1996). The culture of education (pp. 130149). Cambridge: Harvard University Press.

Cai, L., \& Hall, C. (2015). Motivations, expectations, and experiences of expatriate academic staff on an international branch campus in China. Journal of Studies in International Education, 20(3), 207-222.

Cantwell, B., \& Kauppinen, I. (Eds.). (2014). Academic capitalism in the age of globalization. Baltimore: Johns Hopkins Press.

Castles, S., \& Miller, M. J. (2009). The age of migration. International population movements in the modern world (4th ed.). New York: Palgrave Macmillan.

Chou, H.-M., \& Gornitzka, Å. (2014). Building the knowledge economy in Europe: new constellations in European research and higher education governance. Cheltenham: Edward Elgar.

Clandinin, D. J., \& Connelly, F. M. (2000). Narrative inquiry. San Francisco: Jossey Bass.

Clifford, V., \& Montgomery, C. (2014). Challenging conceptions of western higher education and promoting graduates as global citizens. Higher Education Quarterly, 68(1), 28-45.

Connell, R. (2007). Southern theory. London: Allen \& Unwin.

Council of the European Union (2009). Council conclusions of 12th May 2009 on a strategic framework for European cooperation in education and training. [2009/C 119/02]. Brussels: The Council of the European Union.

Cresswell, T. (2010). Towards a politics of mobility. Environment and Planning D: Society and Space, 28, 17-31.

Cresswell, T. (2014). Friction. In A. Petal (Ed.), The Routledge handbook of mobilities (pp. 107-115). London: Routledge.

de Sousa Santos, B. (2014). Epistemologies of the south: justice against epistemicide. Boulder: Paradigm Publishers.

De Wit, H., Hunter, F., Howard, L., \& Egron-Polak, E. (2015). Internationalisation of higher education. Brussels: European Parliament.

Egron-Polak, E., Hudson, R. (2014). Internationalisation of higher education : growing expectations, fundamental values. IAU $4^{\text {th }}$ Global Survey. http://www.iau-aiu.net/sites/all/files/IAU-4th-GLOBAL-SURVEYEXECUTIVE-SUMMARY.pdf. Accessed 20 September 2016.

EHEA. (2012). Making the most of our potential: consolidating the European higher education area. Bucharest: Bucharest Communiqué. EHEA Ministerial Conference http://media.ehea.info/file/2012_Bucharest/67 /3/Bucharest_Communique_2012_610673.pdf. Accessed 14 Oct 2016.

EHEA (2015). Bologna Process Implementation Report. http://eacea.ec.europa.eu/education/eurydice/ documents/thematic_reports/182EN.pdf. Accessed 14 October 2016. 
Equality Challenge Unit (ECU). (2009). Internationalising equality, equalising internationalisation: the intersection between internationalisation and equality and diversity in higher education: scoping report. London: Equality Challenge Unit.

Equality Challenge Unit (ECU). (2010). Internationalisation and equality and diversity in higher education: merging identities. London: Equality Challenge Unit.

Equality Challenge Unit (ECU). (2011). Joining up agendas: internationalisation and equality and diversity in higher education. London: Equality Challenge Unit.

Equality Challenge Unit (ECU). (2013). Improving the experiences of international staff in UK higher education. London: Equality Challenge Unit.

Equality Challenge Unit (ECU). (2014). The rationale for equality and diversity: how vice-chancellors and principals are leading change. London: Equality Challenge Unit.

European Commission (2013). Why European universities need to think global. Speech by Androulla Vassiliou to the European Higher Education in the World conference, Vilnius. (europa.eu/rapid/pressrelease_SPEECH-13-678_en.htm Accessed, 09-09-2016).

Fahey, J., \& Kenway, J. (2010). Thinking in a 'worldly' way: mobility, knowledge, power and geography. Discourse: Studies in the Cultural Politics of Education, 31(5), 627-640.

Fricker, M. (2007). Epistemic injustice: power and the ethics of knowing. Oxford: Oxford University Press.

Gibbs, G. (2007). Analyzing qualitative data. London: Sage.

Giorgi, A., and Raffini, L., (2015) Love and Ryanair: academic researchers' mobility, Forum Sociológico [Online], 27. : https://doi.org/10.4000/sociologico.1327.

Gramsci, A. (1995). Further selections from the prison notebooks. Ed. and trans. Derek Boothman. Minneapolis, $M N$. Minnesota: University Press.

Guruz, K. (2011). Higher education and international student mobility in the global knowledge economy. Albany: State University of New York.

Guth, J., \& Gill, B. (2008). Motivations in east-west doctoral mobility: revisiting the question of brain drain. Journal of Ethnic and Migration Studies, 34(5), 825-841.

HESA. (2009). Resources of higher education institutions 2007/08. Cheltenham: Higher Education Statistics Agency.

Hoffman, D. (2009). Changing academic mobility patterns and international migration: what will academic mobility mean in the 21st century. Journal of Studies in. International Higher Education, 13(3), 347-364.

Jessop, B. (2016). Putting higher education in its place in (East Asian) political economy. Comparative Education, 52(1), 8-25.

Jöns, H. (2007). Transnational mobility and the spaces of knowledge production: a comparison of global patterns, motivations and collaborations in different academic fields. Social Geography, 2, 97-114.

Jöns, H. (2011). Transnational academic mobility and gender. Globalisation, Societies and Education, 9(2), 183209.

Kim, T. (2008). Transnational academic mobility in a global knowledge economy: comparative and historical motifs. In D. Epstein et al. (Eds.), World yearbook of education 2008: geography of knowledge, geometries of power: framing the future of higher education (pp. 319-337). London: Routledge.

Kim, T. (2009a). Transnational academic mobility, internationalisation and interculturality. Intercultural Education, 20, 395-405.

Kim, T. (2009b). Shifting patters of transnational academic mobility: a comparative and historical approach. Comparative Education, 45(3), 387-403.

Kim, T. (2010). Transnational academic mobility, knowledge and identity capital. Discourse: Studies in the Cultural Politics of Education, 31(5), 577-591.

Kim, T. (2016). Internationalisation and development in East Asian higher education: an introduction. Comparative Education, 52(1), 1-7.

Kim, T. (2017) Academic mobility, transnational identity capital, and stratification under conditions of academic capitalism. Keynote presentation at CHEER Seminar: Disrupting Internationalisation Discourses: Discussing Equity and Inclusion, University of Sussex, 19 July 2017.

Kim, T., \& Locke, W. (2010). Transnational academic mobility and the academic profession. In J. Brennan, L. Arthur, B. Little, A. Cochrane, R. Williams, W. Locke, M. Singh, M. David, T. Kim, \& R. King (Eds.), Higher education and society: a research report. London: The Open University.

Krzaklewska, E. (2008). Why study abroad? An analysis of Erasmus students' motivations. In M. Byram \& F. Dervin (Eds.), Students, staff and academic mobility in higher education (pp. 82-98). Cambridge: Cambridge Scholars Publishing.

Kyvik, S., Karseth, B., Remme, J. A., \& Blume, S. (1999). International mobility among Nordic doctoral students. Higher Education, 38, 379-400.

Leemann, R. J. (2010). Gender inequalities in transnational academic mobility and the ideal type of academic entrepreneur. Discourse: Studies in the Cultural Politics of Education, 31(5), 605-625. 
Leung, M. W. H. (2017). Social mobility via academic mobility: reconfigurations in class and gender identities among Asian scholars in the global north. Journal of Ethnic and Migration Studies. https://doi.org/10.1080 /1369183X.2017.1314595.

Lomer, S. (2016). Soft power as a policy rationale for international education in the UK: a critical analysis. Higher Education. https://doi.org/10.1007/s10734-016-0060-6.

Lynch, K. (2009). Carelessness: a hidden Doxa of higher education. Paper presented at the Centre for Higher Education and Equity Research (CHEER) ESRC Seminar Series Imagining the University of the Future. http://www.sussex.ac.uk/education/cheer/esrcseminars/seminar2. Accessed 6 Sept 2016.

MacLure, M. (2013). Researching without representation? Language and materiality in post-qualitative methodology. International Journal of Qualitative Studies in Education, 26(6), 658-667.

Maestri, G. (2017). Are they nomads, travellers or Roma? An analysis of the multiple effects of naming assemblages. Area, 49(1), 18-24.

Matus, C., \& Talburt, S. (2009). Spatial imaginaries: universities, internationalization, and feminist geographies. Discourse: Studies in the Cultural Politics of Education., 30(4), 515-527.

Merrill, B., \& West, L. (2009). Using biographical methods in social research. London: Sage.

Mignolo, W. (2009). Epistemic disobedience, independent thought and decolonial freedom. Theory, Culture \& Society, 26(7-8), 1-23.

Miller, R. (2000). Researching life stories and family stories. London: Sage.

Morano-Foadi, S. (2005). Scientific mobility, career progression, and excellence in the European research area. International Migration, 43(5), 133-160.

Morley, L. (1999). Organising feminisms: the micropolitics of the academy. London: Macmillan.

Morrice, L. (2017). The Global Crisis of Refugee Education: the neglect of young people and adults. Keynote presentation at CHEER Seminar: Disrupting Internationalisation Discourses: Discussing Equity and Inclusion, University of Sussex, 19 July 2017.

Mountz, A. (2010). Seeking asylum: human smuggling and bureaucracy at the border. Minneapolis: University of Minnesota Press.

Musselin, C. (2004). Towards a European academic labour market? Some lessons drawn from empirical studies on academic mobility. Higher Education, 48(1), 55-78.

OECD. (2004). Internationalisation and trade in higher education: opportunities and challenges. Paris: OECD Publishing. https://doi.org/10.1787/9789264015067-en Accessed 14 October 2016.

OECD. (2012). Approaches to internationalisation and their implications for strategic management and institutional practice. A guide for higher education institutions. Paris: OECD https:/www.oecd.org/edu/imhe/Approaches\%20 to\%20internationalisation\%20-\%20final\%20-\%20web.pdf. Accessed 14 Oct 2016.

Omobowale, A. O., \& Akanle, O. (2017). Asuwada epistemology and globalised sociology: challenges of the south. Sociology, 51(1), 43-59.

Pavlin, S., Dezelan, T., \& Svetlik, I. (2013). Challenges of citizenship in higher education: shifting visions, roles and outcomes. Series Sozialwissenschaftliche Beobachtungen, (2). Wien: Edition Echoraum.

Pherali, T. J. (2012). Academic mobility, language, and cultural capital. The experience of transnational academics in British higher education institutions. Journal of Studies in International Education, 16(4), 313-333.

Poole, G. S. (2016). Administrative practices as institutional identity: bureaucratic impediments to HE 'internationalisation' policy in Japan. Comparative Education, 52(1), 62-77.

Richardson, J., \& Zikic, J. (2007). The darker side of an international academic career. Career Development International, 12(2), 164-186.

Riessman, C. K. (2008). Narrative methods for the human sciences. London: Sage.

Roberts, B. (2002). Biographical research. Buckingham: Open University Press.

Robertson, S. (2010). Critical response to special section: international academic mobility. Discourse: Studies in the Cultural Politics of Education, 31(5), 641-647.

Said, E. W. (1994). Intellectual exile: expatriates and marginals. In E. W. Said (Ed.), Representations of the intellectual-the 1993 Reith lectures (pp. 35-47). London: Vintage.

Sheller, M. (2014). The new mobilities paradigm for a live sociology. Current, 62(6), 789-811.

Sheller, M., \& Urry, J. (2006). The new mobilities paradigm. Environment and Planning, 38(2), 207-226.

Skeggs, B. (2004). Class, self, culture. London: Routledge.

Stier, J. (2004). Taking a critical stance toward internationalization ideologies in higher education: idealism, instrumentalism and educationalism. Globalisation, Societies and Education, 2(1), 83-97.

Streitwieser, B. (Ed.). (2014). Internationalisation of higher education and global mobility. Oxford: Symposium Books.

Stromquist, N. (2007). Internationalization as a response to globalization: radical shifts in university environments. Higher Education, 53, 81-105.

Teichler, U., Arimoto, A., \& Cummings, W. K. (2013). The changing academic profession: major findings of a comparative survey. Dordrecht: Springer. 
Urry, J. (2007). Mobilities. London: Polity Press.

UUK. (2007). Talent wars: the international market for academic staff, policy briefing, July 2007. London: Universities UK.

Verger, A. (2010). WTO/GATS and the global politics of higher education. New York: Routledge.

Verger, A., \& Hermo, J. P. (2010). The governance of higher education regionalisation: comparative analysis of the Bologna Process and MERCOSUR-Educativo. Globalisation, Societies and Education, 8(1), 105-120.

Vincent-Lancrin, S., \& Pfotenhauer, S. (2012). Guidelines for quality provision in cross-border higher education: where do we stand? OECD Education Working Paper Series. Paris: OECD.

Walkerdine, V. (2003). Reclassifying upward mobility: femininity and the neo-liberal subject. Gender and Education, 15(3), 237-248.

Wende, M.C. van der (2015). International academic mobility: towards a concentration of the minds in Europe. In, The European Review. Cambridge University Press. Volume 23, issue S1, pp. S70-S88.

Wengraf, T. (2001). Qualitative research interviewing. London: Sage http://www.sussex.ac. uk/education/cheer/researchprojects/rise/trainingmodule. 